\title{
Plackett-Burman Factorial Design for the Optimization of a Spectrophotometric Flow Injection Method for Phenol Determination in Tap and Bottled Water Using 4-Aminoantipyrine
}

\author{
E. G. Carrillo-Cedillo, ${ }^{1}$ M. P. Haro-Vázquez, ${ }^{1}$ G. C. Díaz Trujillo, ${ }^{1}$ and M. P. Cañizares-Macías ${ }^{2 *}$ \\ ${ }^{1}$ Universidad Autónoma de Baja California, FCQI, Calzada Universidad No.14418 Parque Industrial Internacional Tijuana, \\ Baja California, 22390, México \\ ${ }^{2}$ Facultad de Química, Departamento de Química Analítica, Universidad Nacional Autónoma de México, México D.F., 04510, \\ México.pilarm@unam.mx
}

Received August 26 ${ }^{\text {th }}$,2013; Accepted January 9 $9^{\text {th }}, 2014$

\begin{abstract}
Plackett-Burman and Quarter fraction $2^{5-2}$ factorial designs were applied to evaluate a spectrophotometric flow injection method in order to determine phenol in water by using 4-aminoantipyrine (4-AAP) as derivatizing reagent. With a minimum number of experiments, the designs enabled the best conditions for phenol analysis: 80 $\mathrm{cm}$ and $180 \mathrm{~cm}$ reactors; flow-rates being: $\mathrm{NH}_{3} 1.0 \mathrm{~mL} \mathrm{~min}^{-1}$; 4-AAP $0.35 \mathrm{~mL} \mathrm{~min}^{-1}$ and $\mathrm{K}_{3}\left[\mathrm{Fe}(\mathrm{CN})_{6}\right] 0.35 \mathrm{~mL} \mathrm{~min}^{-1}$, [ $\left.\mathrm{NH}_{3}\right] 0.064 \mathrm{~mol}$ $\mathrm{L}^{-1}$, [4-AAP] $9.84 \times 10^{-3} \mathrm{~mol} \mathrm{~L}^{-1},\left[\mathrm{~K}_{3}\left[\mathrm{Fe}(\mathrm{CN})_{6}\right]\right] 0.02 \mathrm{~mol} \mathrm{~L}^{-1}$, and an injection volume of $200 \mu \mathrm{L}$. With the optimized method it was possible to increase the lineal range from $0.3 \mu \mathrm{g} \mathrm{mL}^{-1}$ to $30 \mu \mathrm{g} \mathrm{mL} \mathrm{L}^{-1}$ and also to quantify the maximum allowable phenol concentration in water in comparison with other standard and flow injection methods whose lineal range are from $0.5 \mu \mathrm{g} \mathrm{mL}^{-1}$ to $20 \mu \mathrm{g} \mathrm{mL}^{-1}$ and from $0.5 \mu \mathrm{g} \mathrm{mL}^{-1}$ to $16 \mu \mathrm{g} \mathrm{mL}^{-1}$, respectively. The detection limit was of $0.13 \mu \mathrm{g} \mathrm{mL}^{-1}$ and the regression coefficient was of 0.9999 , making possible a throughput of 36 determinations an hour with a minimum consume of reagent. With the proposed method, a distillation step was not necessary to remove sulfates but, when the sulfate:phenol ratio was higher than 83 , the analytical signal for phenol increased $8 \%$, but hypochlorite interfered with the signal when the hypochlorite:phenol ratio was higher than 1 .
\end{abstract}

Key words: Plackett-Burman factorial design, phenol, 4-aminoantipyrine, water, flow injection, spectrophotometry.

\section{Introduction}

The determination of phenols in the environment is of paramount importance due to their constant presence in industry. Phenolic compounds are used to manufacture insecticides, herbicides, detergents, pharmaceutical products, synthetic resins and disinfectants $[1,2]$. Although the main origin of the existence of phenolic compounds in the environment is anthropogenic, they are also produced by seaweed, plants and animal urine [3-5]. Phenolic compounds are sometimes found in surface water from both natural and industrial sources. Their presence in streams and other waterways frequently causes off flavor in fish tissue and other edible sea plants. On the other hand, chlorination of waters containing phenols may produce chlorophenols, which are odoriferous and also cause an objectionable taste.

Phenol is described by the Environmental Protection Agency [6] as a dangerous compound due to its toxicity, its bioaccumulation and persistency in the environment, as well as its carcinogenic properties. In 2011, phenol was given 688.4
Resumen. Se utilizaron diseños factoriales Plackett-Burman y fraccionado $2^{5-2}$ para evaluar un método espectrofotométrico de inyección en flujo con el objetivo de determinar fenol en agua utilizando 4-aminoantipirina (4-AAP) como reactivo derivatizante. Los diseños establecieron, con la menor cantidad de experimentos, las mejores condiciones para el análisis de fenol fueron: reactores de $80 \mathrm{~cm}$ y 180 $\mathrm{cm}$; caudales para $\mathrm{NH}_{3}$ de $1.0 \mathrm{~mL} \mathrm{~min}^{-1}$; para 4-AAP de $0.35 \mathrm{~mL} \mathrm{~min}^{-1}$ y para $\mathrm{K}_{3}\left[\mathrm{Fe}(\mathrm{CN})_{6}\right]$ de $0.35 \mathrm{~mL} \mathrm{~min}^{-1}$; las concentraciones óptimas fueron $\mathrm{NH}_{3} 0.064 \mathrm{~mol} \mathrm{~L}^{-1}$, 4-AAP $9.84 \times 10^{-3} \mathrm{~mol} \mathrm{~L}^{-1}$ y K $3\left[\mathrm{Fe}(\mathrm{CN})_{6}\right]$ $0.02 \mathrm{~mol} \mathrm{~L}^{-1}$ con un volumen de inyección de $200 \mu \mathrm{L}$. El método una vez optimizado permitió incrementar el intervalo lineal de $0.3 \mu \mathrm{g} \mathrm{mL}^{-1}$ a $30 \mu \mathrm{g} \mathrm{mL}^{-1}$ en comparación con otros métodos estándar y de flujo continuo cuyos intervalos lineales son de $0.5 \mu \mathrm{g} \mathrm{mL}^{-1}$ a $20 \mu \mathrm{g} \mathrm{mL}^{-1}$ y de $0.5 \mu \mathrm{g} \mathrm{mL}^{-1}$ a $16 \mu \mathrm{g} \mathrm{mL}^{-1}$, respectivamente. El límite de detección fue $0.13 \mu \mathrm{g} \mathrm{mL}^{-1}$ y el coeficiente de regresión 0.9999 , con una frecuencia de muestreo de 36 determinaciones por hora y un mínimo consumo de reactivos. Con el método propuesto no fue necesario un paso de destilación para remover sulfatos pero cuando la proporción de sulfato:fenol fue mayor a 83 la señal analítica para fenol incrementó $8 \%$. El hipoclorito interfirió en la cuantificación de fenoles cuando la proporción hipoclorito:fenol fue mayor a 1.

Palabras clave: Diseño factorial Plackett-Burman, fenol, 4-aminoantipirina, agua, inyección en flujo,espectrofotometría.

points by the Agency for Toxic Substances and Disease Registry (ATSDR), reaching the 179th position on a list of toxic compounds where values are based on three criteria: frequency, toxicity and their potential for human exposure [7]. Phenolic compounds affect taste and odor of natural and tap water. Besides, fish, animals and plants suffer from its toxic effects as phenol is absorbed through skin and cellular membranes [8]. Because of its high toxicity, mainly as chlorophenols, routine controls in water and soil are absolutely necessary. Being phenol concentration very low, its determination requires preconcentration processes using chromatography methods [9] For the determination of phenol in water, several methods have used pervaporation coupled to flow injection analysis with amperometric detection, with lineal range from 1 to $50 \mu \mathrm{g} \mathrm{mL}^{-1}$ [4]. Besides, enzymatic methods for determination in urine have also been used [10]. In Mexico, the concentration of phenol and derivatives in tap water was established by the modification of the Mexican Standard NOM-127-SSA1-1994 [11], when $0.3 \mu \mathrm{g} \mathrm{mL} \mathrm{m}^{-1}$ was established as the maximum permissible limit. 
The Mexican Standard NMX-AA-050-SCFI-2001 [12] and the ASTM method [13] have established the test method for the determination of total phenolic compounds applicable to water containing more than $0.1 \mu \mathrm{g} \mathrm{mL} L^{-1}$, although some laboratories have reported to be able to measure concentration as low as $0.005 \mu \mathrm{g} \mathrm{mL}^{-1}$ by using $10 \mathrm{~cm}$ absorption cells. The standard method is based on oxidative coupling of phenols with 4-aminoantipyrine (4-AAP) in alkaline solution to form red antipyrine color, which is measured at $510 \mathrm{~nm}$, so any time that color is produced by the reaction of all phenolic compounds, it is reported as phenol. Phenolic compounds with a substituent in the para position may not quantitatively produce color with 4-AAP. However, para substituents of phenol such as carboxyl, halogen, hydroxyl, methoxyl or sulfonic acid groups do produce color with 4-AAP [14-15]. Morita and Nakamura [16] have also used an ammonium peroxodisulfate solution as oxidizing reagent for the determination of phenol, instead of potassium hexacyanoferrate (III) on the 4-aminoantipyrine determination. Suitable color development was obtained by the addition of from $1 \mathrm{~mL}$ to $5 \mathrm{~mL}$ of ammonium peroxodisulfate solution $(\mathrm{pH}$ $10,220 \mathrm{mmol} \mathrm{L}^{-1}$ ) and $2 \mathrm{~mL}$ of 4-aminoantipyrine solution (98 mmol L ${ }^{-1}$ ), to a $100 \mathrm{~mL}$ sample solution at $\mathrm{pH} 10$ buffered with an ammonium chloride-ammonia solution $\left(9.8 \mathrm{~mol} \mathrm{~L}^{-1}\right)$.

There are many methods where 4-AAP is used as color reagent, including the official standard methods. By flow injection analysis some methodologies have been able to determine very low phenol concentrations but by using a high injection volume $(800 \mu \mathrm{L})$ and also high flow-rates, which causes an increase in the volume of the reagents used $\left(0.8 \mathrm{ml} \mathrm{min}^{-1}\right.$ for 4-AAP and $1.2 \mathrm{ml} \mathrm{min}^{-1}$ for potassium hexacyanoferrate (III) [17-18]. Other authors have evaluated the system used by Frenzel et al. in 1992 by decreasing the injection volume to $400 \mu \mathrm{L}$, but the volume of reagents and the sampling throughput was the same [19]. These methods have enabled measuring concentrations of phenol from $0.5 \mu \mathrm{g} \mathrm{mL}^{-1}$, a concentration higher than the permissible minimum.

The Plackettt-Burman experimental design is used to identify the most important factors early in the experimentation phase, when complete knowledge about the system is usually unavailable. Developed in 1946 by statisticians Robin L. Plackettt and J.P. Burman, it is an efficient screening method for identifying the active factors with as few experimental runs as possible.

In Plackettt-Burman designs, main effects have a complicated confounding relationship with two-factor interactions. Therefore, these designs should be applied to study main effects when it can be assumed that two-way interactions are negligible. In actual use, both the two-level full or fractional factorial designs, as well as the Plackettt-Burman designs are often used to screen the main factors that influence process output measures or product quality. These designs are useful for fitting first-order models (which detect lineal effects) and can provide information on the existence of second-order effects (curvature) when the design includes center points [20].

With the aim of increasing the lineal range for the reaction between phenol, 4-AAP and potassium hexacyanoferrate (III), a flow injection manifold Plackett-Burman design and Quarter fraction $2^{5-2}$ factorial ones were used. Main factors such as injection volume, concentration of reagents, flow-rates and length of reactors were studied and optimized. The effect of sulfates and hypochlorite on the reaction of phenol with 4-AAP and potassium hexacyanoferrate (III) was also evaluated. The method was applied to tap and bottled water.

\section{Results and Discussion}

\section{Optimization of the Flow Manifold}

Plackett-Burman Factorial Design

The flow injection manifold (Fig. 1) was constructed based on the process established by the Mexican standard method, where the sample is first mixed with $\mathrm{NH}_{3}$ and 4-AAP and then $\mathrm{K}_{3}[\mathrm{Fe}(\mathrm{CN})]_{6}$ is added to this solution. By using the manifold shown in Fig. 1, the first test was carried out under the following conditions: $100 \mu \mathrm{L}$ as injection volume, flow-rate of every channel at $0.5 \mathrm{~mL} \mathrm{~min}{ }^{-1},\left[\mathrm{~K}_{3}\left[\mathrm{Fe}(\mathrm{CN})_{6}\right]\right]=0.25 \mathrm{~mol} \mathrm{~L}^{-1}$, [4AAP $]=9.84 \times 10^{-3} \mathrm{~mol} \mathrm{~L}^{-1},\left[\mathrm{NH}_{3}\right]=0.5 \mathrm{~mol} \mathrm{~L}^{-1}$, and length of the reactors $\left(R_{1}\right.$ and $\left.R_{2}\right)=100 \mathrm{~cm}$. For this test the selected reagents concentrations were based on the original concentrations of the standard methods.

The analytical signal obtained was low but the peak was well defined (Gaussian form). Another test was carried out by changing the lengths of the reactors (to $150 \mathrm{~cm}$ ), which resulted in a small increase of the signal. Therefore, a $2^{7 \times 3 / 32}$ PlackettBurman factorial design was constructed in accordance with previous studies, in order to evaluate reagent concentrations, reactors length and flow-rate, as well as injection volume. Table 1 shows the Plackett-Burman experimental design used with three central points, resolution III and three grades of freedom. The ANOVA results are shown in Table 2. The study was carried out at $95 \%$ confidence level, so $\mathrm{P}$ values are less than 0.05 , indicating that they are significantly different from zero. The analysis of residuals showed a random pattern confirming the validity of the model. According to the ANOVA table, at least two effects (injection volume and 4-AAP concentration) are higher than the experimental error for a $95 \%$ confidence

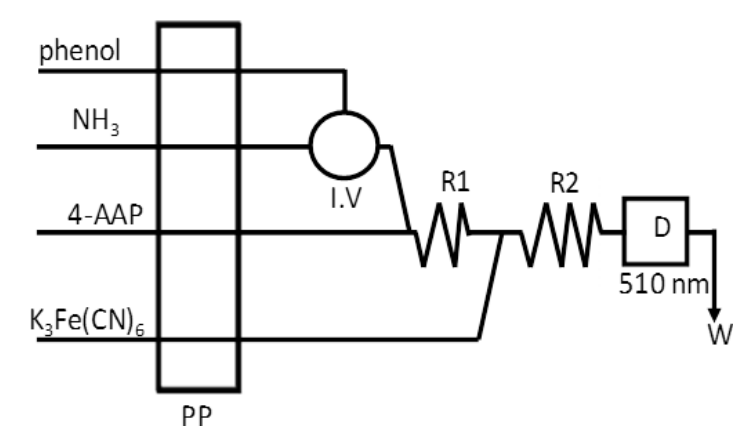

Fig. 1. Flow injection manifold to determine phenol. (4-AAP) 4aminoantipiryne; $R$ : reactors $R_{1}=80 \mathrm{~cm}, R_{2}=180 \mathrm{~cm}$. V.I. Injection valve; PP: peristaltic pump; W: waste. 
Table 1. Plackett-Burman factorial design type III used to evaluate seven variables related with the flow injection manifold.

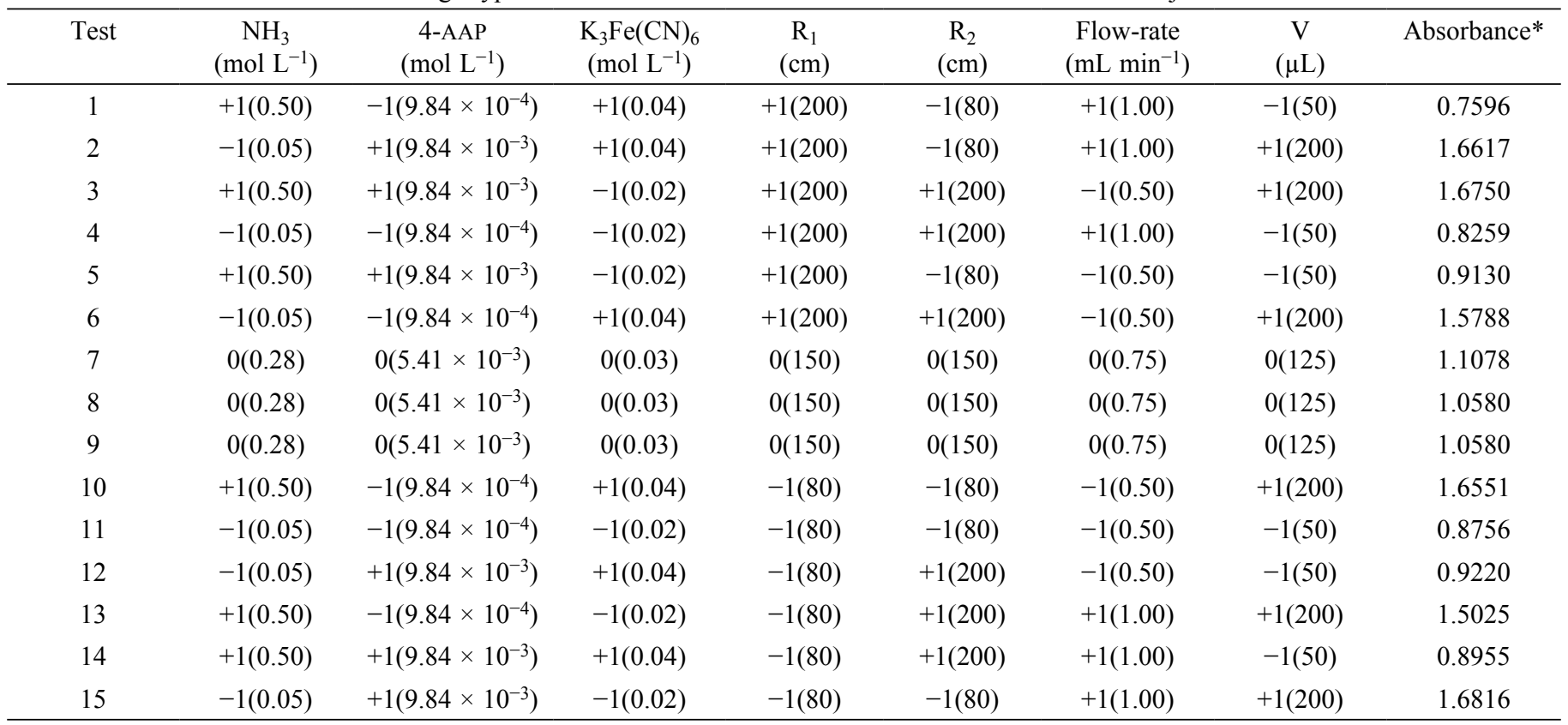

*Mean of three determinations.

interval. The adjusted R-squared, which is more suitable for comparing models with different numbers of independent variables, was $96.68 \%$. The equation of the fitted model is:

$$
\begin{gathered}
A=0.4635-0.0545 x\left[\mathrm{NH}_{3}\right]+10.332 x[4-\mathrm{AAP}]- \\
0.0275 x\left[\mathrm{Fe}(\mathrm{CN})_{6}{ }^{3-}\right]-0.00022 x R_{1}-0.00011 x R_{2}- \\
0.0983 x \text { Flowrate }+0.00615 x \text { Volume }
\end{gathered}
$$

The optimum values were: $\left[\mathrm{NH}_{3}\right] 0.064 \mathrm{~mol} \mathrm{~L}^{-1}$ at $\mathrm{pH}$ 10.5, [4-AAP] $9.80 \times 10^{-3} \mathrm{~mol} \mathrm{~L}^{-1},\left[\mathrm{~K}_{3}[\mathrm{Fe}(\mathrm{CN})]_{6}\right] 0.02 \mathrm{~mol} \mathrm{~L}^{-1}$, a flow-rate of $0.5 \mathrm{~mL} \mathrm{~min}{ }^{-1}$ and the length of the reactors of $80 \mathrm{~cm}$. As the injection volume was the most important factor, volumes higher than $200 \mu \mathrm{L}$ were studied. A volume of $400 \mu \mathrm{L}$ was evaluated under optimum conditions in accordance with the design, but the signal only increased by $3 \% .200 \mu \mathrm{L}$ was the

Table 2. Analysis of variance (ANOVA) at $95 \%$ of confidence level from the results of the Plackett-Burman factorial design type III factorial design.

\begin{tabular}{lcccc}
\hline Source & Sum of Squares & Df & Mean Square & P-Value \\
\hline A:[NH & 0.00187194 & 1 & 0.00187194 & 0.5301 \\
B:[4-AAP] & 0.0253369 & 1 & 0.0253369 & $\mathbf{0 . 0 4 5 4}$ \\
$\mathrm{C}:\left[\mathrm{K}_{3} \mathrm{Fe}(\mathrm{CN})_{6}\right]$ & $6.75 \mathrm{E}-08$ & 1 & $6.75 \mathrm{E}-08$ & 0.9969 \\
$\mathrm{D}: \mathrm{R}_{1}$ & 0.00253307 & 1 & 0.00253307 & 0.4675 \\
$\mathrm{E}: \mathrm{R}_{2}$ & 0.00100693 & 1 & 0.00100693 & 0.6429 \\
$\mathrm{~F}:$ Flow-rate & 0.00713944 & 1 & 0.00713944 & 0.2381 \\
G:Volume & 1.78334 & 1 & 1.78334 & $\mathbf{0 . 0 0 0 0}$ \\
Total error & 0.0300421 & 7 & 0.00429173 & \\
Total (corr.) & 1.85125 & 14 & & \\
\hline
\end{tabular}

nearest volume to $S_{1 / 2}(189.88 \mu \mathrm{L})$, which is the sample volume necessary for the dispersion to be equal to 2 . This value was calculated from the following equation (Equation 2) [20]:

$$
-\log \left[1-\frac{A_{\max }}{A_{0}}\right]=\frac{-0.693}{2.303 S_{1 / 2}} S_{v}
$$

where:

$A_{\max }$ is the absorbance of the dispersed sample, $A_{o}$ is the absorbance of the sample without dispersion, $S_{v}$ is volume of sample injected and $S_{1 / 2}$ is the volume of sample necessary for dispersion to be equal to 2 (dilution 1:1).

Therefore $200 \mu \mathrm{L}$ was used for the next optimization tests.

Evaluation of Flow-Rate of the Reagents by Using a Quarter Fraction $2^{5-2}$ Factorial Design

Consequently, a second factorial design $\left(2^{5-2}\right.$ quarter fraction plus three central points) was carried out in order to evaluate the flow-rate for each reagent. In accordance with the manifold and the reaction, the first reactor $\left(\mathrm{R}_{1}\right)$ was only used for mixing of $\mathrm{NH}_{3}$ and 4-AAP with the sample. The second reactor $\mathrm{R}_{2}$ proved to be more important as, in that case, a global reaction of all reagents occurred. Therefore, the length of the reactors $R_{1}$ and $\mathrm{R}_{2}$ as well as the flow-rates of the reagents were included in this design. The used injection volume $(200 \mu \mathrm{L})$ and the concentration of the reagents were the optimum values found in previous designs. Table 3 shows the matrix used. The ANOVA test and pareto chart showed that there was no clear interaction among the evaluated factors. Fig. 2 shows the pareto chart of the main factors. According to the Fig., at least four effects (length of $\mathrm{R}_{2}$, flow-rate 4-AAP, length of $\mathrm{R}_{1}$ and flow rate $\mathrm{K}_{3} \mathrm{Fe}(\mathrm{CN})_{6}$ ) are higher than the experimental error denoted by the vertical 
Table 3. Quarter-fraction $2^{5-2}$ factorial design used to evaluate five variables related whit the flow injection manifold.

\begin{tabular}{|c|c|c|c|c|c|c|}
\hline Test & $\begin{array}{c}\mathrm{NH}_{3} \\
\left.(\mathrm{ml} \mathrm{min})^{-1}\right)\end{array}$ & $\begin{array}{c}\text { 4-AAP } \\
\left.(\mathrm{ml} \mathrm{min})^{-1}\right)\end{array}$ & 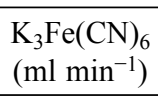 & $\begin{array}{c}\mathrm{R}_{1} \\
(\mathrm{~cm})\end{array}$ & $\begin{array}{c}\mathrm{R}_{2} \\
(\mathrm{~cm})\end{array}$ & Absorbance $^{(a)}$ \\
\hline 1 & $0(0.75)$ & $0(0.60)$ & $0(0.50)$ & $0(140)$ & $0(140)$ & 0.2335 \\
\hline 3 & $+1(1.00)$ & $+1(0.75)$ & $-1(0.35)$ & $+1(200)$ & $-1(100)$ & 0.2172 \\
\hline 4 & $0(0.75)$ & $0(0.60)$ & $0(0.50)$ & $0(140)$ & $0(140)$ & 0.2342 \\
\hline 7 & $-1(0.60)$ & $+1(0.75)$ & $-1(0.35)$ & $-1(80)$ & $+1(180)$ & 0.2733 \\
\hline 8 & $-1(0.60)$ & $+1(0.75)$ & $+1(0.70)$ & $-1(80)$ & $-1(100)$ & 0.2094 \\
\hline 9 & $+1(1.00)$ & $-1(0.35)$ & $-1(0.35)$ & $-1(80)$ & $-1(100)$ & 0.2748 \\
\hline 10 & $-1(0.60)$ & $-1(0.35)$ & $+1(0.70)$ & $+1(200)$ & $-1(100)$ & 0.2139 \\
\hline
\end{tabular}

(a) Average of three deteminations

line indicating its $95 \%$ confidence interval, where the analytical signal of the product of the reaction shows no dependence on the flow-rate of $\mathrm{NH}_{3}$, but a strong influence of the length of $\mathrm{R}_{2}$. With smaller influence, the flow-rate of 4-AAP, the length of $\mathrm{R}_{1}$ and the flow-rate of $\mathrm{K}_{3} \mathrm{Fe}\left(\mathrm{CN}_{6}\right)$, gave better signal at lower values. As the length of $R_{1}$ had a negative influence on the analytical signal, several experiments were studied at lengths lower than $80 \mathrm{~cm}$. The signal obtained was smaller than $80 \mathrm{~cm}$ and the mixing of $\mathrm{NH}_{3}$ and 4-AAP was not suitable. The flow-rates of 4-AAP and $\mathrm{K}_{3} \mathrm{Fe}\left(\mathrm{CN}_{6}\right)$ and the length of $\mathrm{R}_{2}$ were selected in accordance with the results of the codified equation describing the dependency on the variable response (Equation 3).

$$
\begin{gathered}
A=0.2565+0.0155 x \text { flowrate } \mathrm{NH}_{3}- \\
0.0714 x \text { flowrate 4-AAP }-0.0532 x \text { flowrate } \\
\mathrm{K}_{3} \mathrm{Fe}\left(\mathrm{CN}_{6}\right)-0.00023 x R_{1}+0.00051 x R_{2}
\end{gathered}
$$

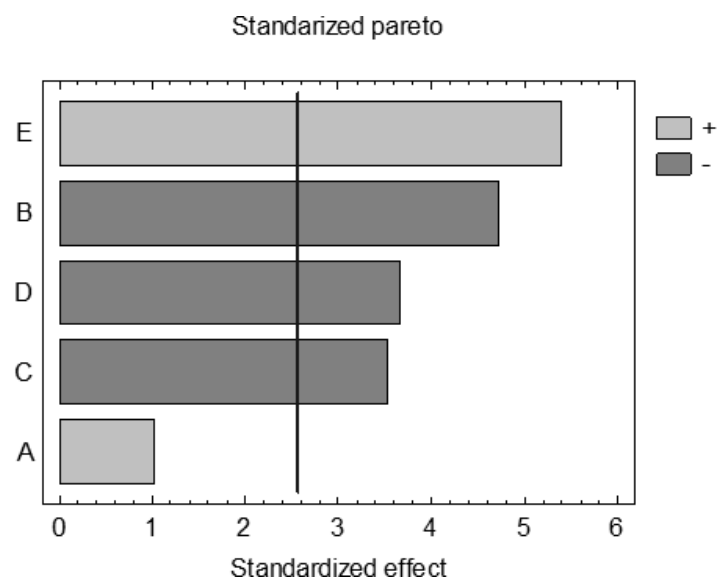

Fig. 2. Pareto chart of standardized effects showing the main effects: A: flow-rate of $\mathrm{NH}_{3}$, B: flow-rate 4-AAP, C: flow rate $\mathrm{K}_{3} \mathrm{Fe}(\mathrm{CN})_{6}$; $\mathrm{D}$ : length of $\mathrm{R}_{1}$; E: length of $\mathrm{R}_{2}$ that significantly contribute to absorbance, according the results of the experimental design matrix shown in Table 3.
In the end, the optimum values in accordance with the factorial designs were: $\mathrm{R}_{1}: 80 \mathrm{~cm} ; \mathrm{R}_{2}: 180 \mathrm{~cm}$; flow-rates: $\mathrm{NH}_{3}$ $1.0 \mathrm{~mL} \mathrm{m^{-1 }}$; 4-AAP $0.35 \mathrm{~mL} \mathrm{~min}^{-1}$ and $\mathrm{K}_{3}[\mathrm{Fe}(\mathrm{CN})]_{6} 0.35$

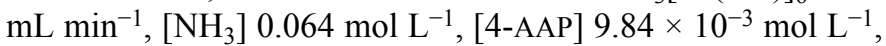
$\left[\mathrm{K}_{3}[\mathrm{Fe}(\mathrm{CN})]_{6}\right] 0.02 \mathrm{~mol} \mathrm{~L}^{-1}$, and injection volume $200 \mu \mathrm{L}$. Flow-rate values lower than $0.35 \mathrm{~mL} \mathrm{~min}^{-1}$ were not tested because the analysis would had been too time consuming.

\section{Characteristics of the Method}

The calibration curve was constructed with an optimized flow injection manifold. The lineal equation was: $0.0336( \pm 2.57 \times$ $\left.10^{-4}\right)[\mathrm{phenol}]-0.0006\left( \pm 3.16 \times 10^{-3}\right)$. The lineal range is from $0.3 \mu \mathrm{g} \mathrm{mL}^{-1}$ to $30 \mu \mathrm{g} \mathrm{mL}^{-1}$, with a detection limit of $0.13 \mu \mathrm{g}$ $\mathrm{mL}^{-1}$ and a regression coefficient of 0.9999 . The precision of the method regarding repeatability, expressed as relative standard deviation, was $1.37 \%$ for $1.0 \mu \mathrm{g} \mathrm{mL}^{-1}$ and $0.82 \%$ for $15 \mu \mathrm{g}$ $\mathrm{mL}^{-1}$. Fig. 3 shows the transient signal of the calibration curve from $0.3 \mu \mathrm{g} \mathrm{mL} L^{-1}$ to $30 \mu \mathrm{g} \mathrm{mL} L^{-1}$. Under optimized working conditions, the analysis time was $1.65 \mathrm{~min}$. by each injection, achieving 36 determinations an hour. Some authors have described how a flow system with higher flow-rates shortens the analysis time (50 determinations an hour) with a lineal range from $0.5 \mu \mathrm{g} \mathrm{mL} L^{-1}$ to $16 \mu \mathrm{g} \mathrm{mL}^{-1}$ [17-19]. With the proposed method it was possible to increase the lineal range with a similar volume of reagents but with an injection volume of only $200 \mu \mathrm{L}$, in comparison with the $400 \mu \mathrm{L}$ reported by Dolatto et al. [19]. For the official spectrophotometric method, the lineal range was from $0.5 \mu \mathrm{g} \mathrm{mL}^{-1}$ to $20 \mu \mathrm{g} \mathrm{mL}^{-1}$.

\section{Analysis of Samples}

Table 4 shows the results for the water samples analyzed together with their recoveries, which were between $92 \%$ and $110 \%$ for the two concentrations of phenol studied. The concentration of the samples was lower than the detection limit $\left(0.13 \mu \mathrm{g} \mathrm{mL}^{-1}\right)$ so the recoveries showed no interference of the matrix. 


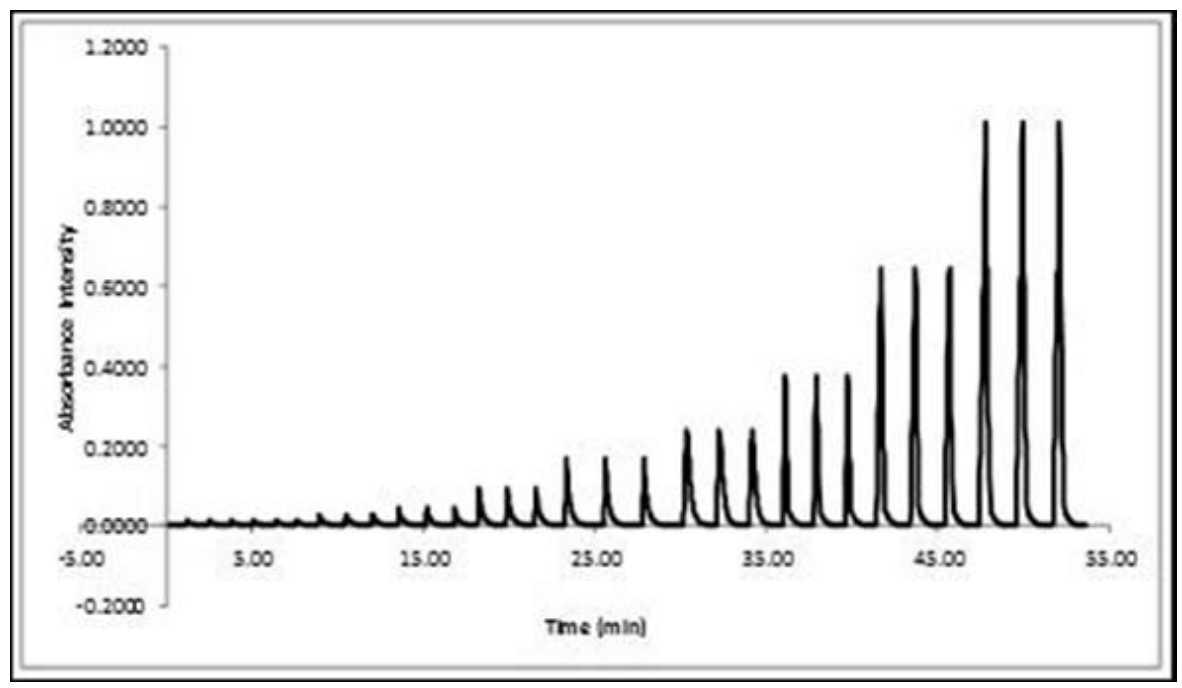

Fig. 3. Transient signals obtained for phenol in a range from $0.3 \mu \mathrm{g} \mathrm{mL}^{-1}$ to $30 \mu \mathrm{g} \mathrm{mL}^{-1}(0.3$, $0.5,0.8,1.0,4.0,6.0,8.0,10.0,20.0$ and $30 \mu \mathrm{g} \mathrm{mL}-1)$; analysis in triplicate.

Table 4. Analysis of water samples.

\begin{tabular}{|c|c|c|c|c|c|c|}
\hline \multirow{3}{*}{ Sample } & \multicolumn{3}{|c|}{ Proposed method } & \multicolumn{2}{|c|}{ Official method } & \\
\hline & \multicolumn{4}{|c|}{ Recoveries (\%) } & \multicolumn{2}{|c|}{ Recoveries (\%) } \\
\hline & \multicolumn{4}{|c|}{ Added } & \multicolumn{2}{|c|}{ Added } \\
\hline Tap water (Coyoacán) & $\mathrm{Nd}$ & 102.1 & $104.5 \pm 0.1$ & $\mathrm{Nd}$ & 96.3 & $102.3 \pm 0.3$ \\
\hline Tap water (Miguel Hidalgo) & $\mathrm{Nd}$ & 96.4 & $102.3 \pm 0.1$ & $\mathrm{Nd}$ & 105.2 & $90.3 \pm 0.1$ \\
\hline Bottle water (Prial) & $\mathrm{Nd}$ & 95.8 & $96.2 \pm 0.2$ & $\mathrm{Nd}$ & 91.6 & $93.2 \pm 0.4$ \\
\hline Bottle water (Aguafiel) & $\mathrm{Nd}$ & 92.1 & $101.8 \pm 0.3$ & $\mathrm{Nd}$ & 90.5 & $95.2 \pm 0.2$ \\
\hline
\end{tabular}

Nd: no detected.

Another study was carried out to evaluate the interferences in the flow injection determination, of other possible compounds that could be present in tap water. Table 5 shows the results. The permissible limits of sulfates and hypochlorite are $400 \mu \mathrm{g} \mathrm{ml}^{-1}$ and $1.5 \mu \mathrm{g} \mathrm{mL}^{-1}$, in natural drinking wastewater and in wastewater treated according with NMX-AA-050-SCFI2001 [12], respectively. The concentration measured in a phenol solution of $12 \mu \mathrm{g} \mathrm{mL}^{-1}$ was $11.8 \pm 0.0025 \mu \mathrm{g} \mathrm{mL}^{-1}$. The results showed no interference when the concentration of hypochlorite ion was lower than the phenol concentration, $\left(\mathrm{OCl}^{-}\right.$ ion at $1.5 \mu \mathrm{g} \mathrm{mL}^{-1}$; phenol: hypochlorite ratio equal to 8 ), in accordance with the $F$ test for equal variance. However, when the hypochlorite ion concentration was the same or higher than the phenol concentration (from $15 \mu \mathrm{g} \mathrm{ml}^{-1}$ to $240 \mu \mathrm{g} \mathrm{mL}^{-1}$ ), the measurement of the phenol concentration decreased by between $15.24 \%$ and $54.49 \%$ at time cero, and between $14.00 \%$ and $79.83 \%$ after $60 \mathrm{~min}$. (Table 5).

As for sulfates, the phenol value increased by $8 \%$ from $1000 \mu \mathrm{g} \mathrm{mL}^{-1}$ of sulfates with a sulfates phenol ratio equal to
83. For ratios lower than 60 , concentrations of sulfates of 240 and $739 \mu \mathrm{g} \mathrm{mL}^{-1}$, there were no interferences in the measurement of phenol.

\section{Conclusions}

1) The optimization of the flow injection determination of phenol with 4-APP by experimental design enabled to reduce the experiments.

2) The proposed method increases the lineal range allowing measuring from $0.3 \mu \mathrm{g} \mathrm{mL}^{-1}$, which is established as the maximum permissible limit by the Mexican Standard NOM127-SSA1-1994, to $30 \mu \mathrm{g} \mathrm{mL}^{-1}$.

3) With the proposed method the possible interferences of sulfates for tap and bottled are avoided, and distillation, as proposed by the standard method, is not necessary.

4) Hypochlorite has to be removed during the sampling. The removal of all hypochlorite ions beforehand is made neces- 
Table 5. Study of interferences for the proposed method. The phenol concentration was $12 \mu \mathrm{g} \mathrm{mL}^{-1}$.

\begin{tabular}{ccc}
\hline $\begin{array}{c}\text { Interference } \\
\text { analyzed }\left(\mu \mathrm{g} \mathrm{ml}^{-1}\right)\end{array}$ & \multicolumn{2}{c}{ Found phenol concentration $\left(\mu \mathrm{g} \mathrm{mL}^{-1}\right)$} \\
\hline \multicolumn{3}{c}{ Time $(\mathrm{min})^{*}$} \\
\hline \multicolumn{3}{c}{60} \\
\hline $\mathrm{OCl}^{-}$ & $11.79 \pm 0.003$ & $11.75 \pm 0.001$ \\
1.5 & $10.00 \pm 0.002$ & $10.15 \pm 0.001$ \\
15 & $7.30 \pm 0.003$ & $4.03 \pm 0.004$ \\
240 & $5.37 \pm 0.005$ & $2.38 \pm 0.001$ \\
$\mathrm{SO}_{4}{ }^{--}$ & & $11.78 \pm 0.001$ \\
250 & $11.75 \pm 0.002$ & $11.88 \pm 0.002$ \\
730 & $11.73 \pm 0.003$ & $12.66 \pm 0.003$ \\
1000 & $12.77 \pm 0.005$ &
\end{tabular}

*Time passed between the additions of the interferences to the phenol solution and the determination of phenol

sary as, otherwise, it would be an important interference in the analysis of total phenols in tap and bottled water.

\section{Experimental}

\section{Instrumentation}

In order to determine phenol, an Ismatec 4 channel peristaltic pump, an injection valve (Upchurch Scientific V451) and teflon tubing of $0.8 \mathrm{~mm}$ i.d. were used to build the flow injection manifold. A UV-Vis spectrophotometer Cary 3 from Varian (Sydney, Australia) equipped with a flow cell of $118 \mu \mathrm{L}$ inner volume was used to measure the reaction product at $510 \mathrm{~nm}$. An ultrasonic bath (Branson) was also used. Statgraphics Plus 4.0 software (Statistical Graphics, Rockville, MD) was used for test design and data analysis.

\section{Reagents and Solutions}

All reagents were analytical grade. 4-aminoantipyrine (4-AAP) (Fisher Scientific, Suwanee, GA, USA), $\mathrm{K}_{3}\left[\mathrm{Fe}(\mathrm{CN})_{6}\right](99 \%$, Sigma-Aldrich, Toluca, Mexico) and $\mathrm{NH}_{3}$ (Baker-Mallinkroft, Mexico City) were used to carry out phenol quantification. The phenol stock solution was prepared by dissolving $100 \mathrm{mg}$ of phenol (99\%, Sigma-Aldrich, Toluca, Mexico) in freshly boiled and cooled water, and diluted to $1000 \mathrm{~mL}$ with the same type of water. This solution was used during a 7 day observation period.

\section{Samples}

Tap water from different districts of Mexico City and bottled water were directly analyzed in triplicate without any pretreatment.

\section{Procedures}

The principle of the reaction is based on the oxidative coupling of phenol with 4-AAP in alkaline solution to form a dye complex, by using a $\mathrm{K}_{3}[\mathrm{Fe}(\mathrm{CN})]_{6}$ solution as oxidizing reagent. The reaction product is measured at $510 \mathrm{~nm}$.

\section{Proposed Flow Injection Analysis Method}

Fig. 1 illustrates the flow injection analysis manifold designed for method implementation. Phenol standard and sample were injected into a $\mathrm{pH} 10 \mathrm{NH}_{3}$ carrier, merged with 4-AAP, and then mixed in reactor $\mathrm{R}_{1}$. Afterwards, the mixture was merged with the $\mathrm{K}_{3}[\mathrm{Fe}(\mathrm{CN})]_{6}$ solution to form the red complex along with reactor $R_{2}$ and it was measured at $510 \mathrm{~nm}$.

\section{Official Spectrophotometric Method}

$5 \mathrm{~mL}$ of a $0.5 \mathrm{~N} \mathrm{NH}_{4} \mathrm{Cl}$ solution were added to each $100 \mathrm{~mL}$ of blank, standards and samples. The $\mathrm{pH}$ was adjusted between 9.8 and 10.2 with $\mathrm{NH}_{3}$ and then $2.0 \mathrm{ml}$ of $2.5 \%$ (w/v) 4-AAP solution was also added and mixed immediately. At this point, $2.0 \mathrm{~mL}$ of $8 \%(\mathrm{w} / \mathrm{v}) \mathrm{K}_{3}\left[\mathrm{Fe}(\mathrm{CN})_{6}\right]$ solution were added and also mixed. After $15 \mathrm{~min}$ the solutions were transferred to an absorption cell and the absorbance was measured at $510 \mathrm{~nm}$.

\section{Validation of the Proposed Flow Injection Method}

First, in order to carry out a screening study of the main factors affecting the reaction, a multifactorial design methodology was built based on a Plackett-Burman factorial design type IV resolution with 4 degrees of freedom, involving 12 randomized runs plus three center points. Seven factors were evaluated, whose top and bottom values were established according to previous studies: $\mathrm{NH}_{3}$ concentration $\left(0.05-0.5 \mathrm{~mol} \mathrm{~L}{ }^{-1}\right)$, 4-AAP concentration $\left(9.84 \times 10^{-4}-9.84 \times 10^{-3} \mathrm{~mol} \mathrm{~L}^{-1}\right), \mathrm{K}_{3}[\mathrm{Fe}(\mathrm{CN})]_{6}$ concentration $\left(0.02-0.04 \mathrm{~mol} \mathrm{~L}^{-1}\right), \mathrm{R}_{1}(80-200 \mathrm{~cm})$ and $\mathrm{R}_{2}(80-200 \mathrm{~cm})$ lengths, flow-rate of the reagents $\left(0.50-1.00 \mathrm{~mL} \mathrm{~min}^{-1}\right)$ and injection volume $(75-200 \mu \mathrm{L})$. Each test was done in triplicate.

A second factorial design based on $2^{5-2}$ quarter fraction type $\mathrm{V}$ resolution allowing four freedom degrees and involving 8 randomized runs plus three centre points was also carried out with the aim of finding the optimal values for the flow-rates of each reagent and the lengths of the reactors: $\mathrm{NH}_{3}(0.6-1 \mathrm{~mL}$ $\left.\min ^{-1}\right)$, 4-AAP $\left(0.35-0.75 \mathrm{~mL} \mathrm{~min}^{-1}\right), \mathrm{K}_{3}[\mathrm{Fe}(\mathrm{CN})]_{6}(0.35-0.7$

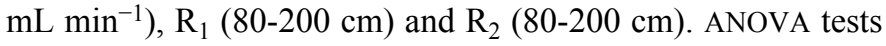
were calculated by Statgraphics software.

The precision of the method was evaluated by repeatability injecting 11 standards of $1 \mu \mathrm{g} \mathrm{mL}^{-1}$ and $15 \mu \mathrm{g} \mathrm{mL} \mathrm{m}^{-1}$. A study of recoveries by adding $15 \mu \mathrm{g} \mathrm{mL}^{-1}$ and $1 \mu \mathrm{g} \mathrm{mL}^{-1}$ to the water samples was also carried out in triplicate with the aim of demonstrating no interferences in the matrix.

\section{Evaluation of Interferences in the Proposed Flow Injection Method}

The most important interferences to measure total phenolic compounds in water are sulfates and hypochlorite. Therefore, different concentration of $\mathrm{Na}_{2} \mathrm{SO}_{4}$ and $\mathrm{NaOCl}$ were added to 12 $\mu \mathrm{g} \mathrm{mL} \mathrm{m}^{-1}$ of phenol solution and the phenol concentration was measured at $0 \mathrm{~min}$ and at $60 \mathrm{~min}$. 


\section{Acknowledgments}

The authors are grateful for the financial assistance provided by the Facultad de Química of the Universidad Nacional Autónoma de México (UNAM), to the Dirección General de Cooperación e Internalización, Subdirección de Movilidad Académica of the UNAM and the $15^{\text {th }}$ Convocatoria Interna de Apoyo a Proyectos de Investigación of the Universidad Autónoma de Baja California, with the project: Aplicación de análisis por inyección en flujo a los subproductos de desinfección de agua. The authors are also grateful to Blanca de la Puente Barrios $\mathrm{PhD}$, for her translation support.

\section{References}

1. Lancas, F. M.; Olivares, I. R. B.; Alves, P. M. J. Environ. Sci. Health Part B. 2007, 42, 491-498.

2. Lupetti, K. O.; Rocha, F. R. P.; Fatibello, O. Talanta 2004, 62, 463-467.

3. Van Schie, P. M.; Young, L. Y. Bioremediat. J. 2000, 4, 1-18.

4. Sheikheldin, S. Y.; Cardwell, T. J.; Cattrall, R.W.; Luque de Castro, M. D.; Kolev, S. D. Anal. Chim. Acta 2000, 419, 9-16.

5. Kamble, S. P.; Mangrulkar, P. A.; Ansiwal, A. K. B.; Rayalu, S. S. Chem. Eng. J. 2008, 138, 73-83.

6. http://water.epa.gov/drink/contaminants/index.cfm, accessed in December, 2012

7. http://www.atsdr.cdc.gov/SPL/index.html, accessed in December, 2012

8. Sousa, A. R.; Trancoso, M. A. Talanta 2009, 79, 796-803.

9. Gavrilenko, M. A.; Gavrilenko, N. A.; Mokrousov, G. M. J. Anal. Chem. 2006, 61, 216-218.
10. Grunhut, M.; Palomeque, M. E.; Lista, A. G; Fernandez Band, B. S. Talanta 2007, 71, 1520-1523.

11. Norma Oficial Mexicana NOM-127-SSA1-1994. Modificación. Salud Ambiental. Agua para uso y consumo humano. Límites permisibles de calidad y tratamientos a que debe someterse el agua para su potabilización. Fecha de Modificación en D.o.F.: 22 de noviembre, $\mathbf{2 0 0 0 .}$

12. Norma Oficial Mexicana NMX-AA-050-SCFI-2001. Análisis de agua- Determinación de fenoles totales en aguas naturales, potables, residuales y residuales tratadas- Método de prueba. Water analysis -Determination of total phenols in natural, drinking, wastewaters and wastewaters treated-Test method. Secretaria de Comercio y Fomento Industrial (SECOFI) México.

13. ASTM, Annual Book of American Society for Testing and Materials (ASTM) Standards. Water and Environmental Technology. Section 11, Volume 11.02 Designation D1783-87. Standard Test Methods for Phenolic Compounds in Water, Philadelphia, PA. 1991, 132-138.

14. http://www.skalar.com/news/sub-ppb-detection-levels-for-totalphenol-analysis-on-the-san/\#.UfpGvo09_zw, accessed in June, 2012

15. ISO (International Organization for Standardization), ISO 14402. Water Quality-Determination of Phenol Index by Flow Analysis (FIA and CFA), 1st ed., ISO, Geneva, Switzerland. 1999.

16. Morita, E.; Nakamura, E. Bunseki Kagaku. 2011, 60, 441-444.

17. Frenzel,W.; Oleksy-Frenzel. J. Anal. Chim. Acta 1992, 261, 253259.

18. Kwade C.; Voigtlander, R.; Cammann, K. Fresenius J. Anal. Chem. 1992, 342, 426-428.

19. Dolatto, R. G.; Messerschmidt, I.; Pereira, B. F.; Silveira, C. A. P.; Abate, G. J. Braz. Chem. Soc. 2012, 23, 970-976.

20. Cerda, V. Introducción a los métodos de análisis en flujo. Departament de Química, Universitat de les Illes Balears E-07122, Palme de Mallorca, Edición SCIWARE S.L. 2006, 33-48. 